\title{
Múgyanta alapú kompozíciós helyreállító anyagok és azok egészségre gyakorolt hatása \\ Irodalmi áttekintés
}

\author{
DR. BARNA BALÁZS KÁROLY, DR. FRÁTER MÁRK
}

\begin{abstract}
A fogorvoslásban napról napra egyre több, újabb anyag áll rendelkezésre a minél tökéletesebb gyógyítás megvalósítása érdekében. Ezen anyagok a fogban vagy a szájüregben önmagukban betöltött helyreállító szerepükön túl azonban egy dinamikusan változó közegben is vannak, ezért az operátornak fel kell ismernie, hogy az említett anyagok ezáltal folyamatosan kölcsönhatásba lépnek nemcsak a közvetlen környezetükkel, hanem az egész szervezettel. Ezért, hasznos tulajdonságaik mellett, ismerni kell mind a lokális, mind a szisztémás hatásaikat, az esetleges szövet- és szervezetkárosító tulajdonságaik eshetőségének elkerülése, minimalizálása céljából. A szerzők a hazai és nemzetközi irodalom széleskörü áttekintése alapján szeretnének ehhez egy összefoglaló írás keretein belül betekintést, iránymutatást nyújtani a manapság rendkívül széles körben elterjedt, szinte minden helyreállító eljárás folyamán alkalmazott mügyanta tartalmú anyagokkal kapcsolatban. Ennek célja az elméleti ismeretek elmélyítése mellett a tényleges, napi ellátás folyamán történő, mind a páciens, mind az egészségügyi személyzet számára biztonságosabb ellátás lehetőségének megteremtése.
\end{abstract}

Kulcsszavak: biokompatibilitás, kompozit, monomer, múgyanta

\section{Bevezetés}

A fogorvostudomány az orvostudományok egyik vezető ágazata a fejlesztések és a megjelenő új anyagok tekintetében. Napjainkban számtalan lehetőség, anyag és technika áll rendelkezésre egy praktizáló fogorvos számára egy adott klinikai szituáció megoldására. Ez azonban veszélyeket is magában foglal, hiszen a fogorvosnak naprakésznek kell lennie az új, alkalmazni kívánt készítmények használati módjaival, továbbá, ami még fontosabb, a páciensre, a személyzetre és a környezetre való hatásaival kapcsolatban. Ezek a készítmények már feldolgozásuk előtt kontaktusba kerülhetnek a fogászati csapattal, alkalmazásuk során mind az egészségügyi dolgozók, mind a páciensek, sőt még a fogtechnikus is ki lehet téve a hatásaiknak. Továbbá ezek az anyagok a szájba kerülésük után közvetlenül a fogorvos által is módosításokon eshetnek át (pl. a restaurátum finírozása, polírozása), majd idővel kophatnak, összetevők oldódhatnak ki, amelyek különböző szövetekkel kerülnek kapcsolatba és azokra hatást fejtenek ki. Azzal is érdemes számolni, hogy idővel eltávolításra fognak kerülni (pl. secunder caries vagy eltörés miatti töméscsere). Ilyenkor a fogászati anyag, valamilyen módon, kikerül a környezetünkbe, ezáltal arra kifejtett, hosszú távú hatásával is számolni kell. Ennek is köszönhető, hogy az ez irányú fogászati kutatások, vizsgálatok, standardok és jogi korlá- tozások a figyelem középpontjába kerültek az elmúlt években.

Jelen összefoglaló írás, széles körü nemzetközi és hazai irodalom felhasználásával, áttekintést szeretne nyújtani a praxisokban napi szinten használt múgyanta-bázisú kompozíciós tömőanyagokról, a közvetlen és távoli környezetükre való hatásaikról, az esetleges rizikókról, azok mértékéről és szükség esetén ezeknek az elkerülését elősegítő lehetőségekről. A gyakorló fogorvosnak tisztában kell lennie az általa használt készítményeknek az emberi szervezetre gyakorolt lokális és szisztémás hatásaival, azok káros tulajdonságai elkerülésének, csökkentésének lehetőségével.

\section{Alapfogalmak, koncepciók}

Kezdetben az elsődleges cél az volt, hogy az alkalmazott anyagok általi kedvezőtlen hatásokat elkerüljék. Ennek a talaján alakult ki a bioinert anyagok fogalma, mely azt feltételezte, hogy a behelyezett anyag és a környező szövetek között semmiféle anyagcsere és kölcsönhatás nem történik. Célja a fogászati anyag alkalmazását követő potenciális szöveti károsodás elkerülése volt [25]. Mivel ez teljes mértékben a gyakorlatban kivitelezhetetlen, a kitǔzött cél a szervezet által tolerált, biokompatibilis anyagok megalkotása lett. A biokompatibilitás tehát nem más, mint egy bioanyag funk- 
ciójának betöltésére való képessége anélkül, hogy mellékhatásként klinikailag szignifikáns káros hatásokat fejtene ki a befogadó szervezetre, környezetre [42]. A harmadik csoportot a bioaktív anyagok alkotják, amelyek esetében valamilyen terápiás célt várunk el, ami legtöbbször egy specifikus biológiai folyamat elindítása, mint a biomineralizáció vagy az antibakteriális aktivitás fokozása [33].

A felhasznált fogászati anyagok a közvetlen környezetükben lévő szövetekre is fejthetnek ki hatást, mint például monomerek hatására történő pulpanekrózis [1, 35], a gingiva gyulladása [37] a restaurátumok mellett kialakuló marginális gingivitis vagy egyéb, fehér színú nyálkahártya-elváltozások [19, 20]. Szisztémás szöveti reakció az alkalmazási területtől távol lévő szervekben léphet fel. Az epitheliális gátak áttörésével az anyagok a vér útján terjedve távoli szervekben felhalmozódhatnak, valamint a szervezetben történő metabolikus átalakulások következtében is kifejthetnek nemkívánatos hatást [33]. Emellett nem szabad elfeledkezni a fogászati szempontból eddig háttérben meghúzódó, kevés figyelmet kapott nanorészecskék szerepéről sem [29, 30], melyekről a későbbiekben még szó lesz. A különféle fogászati anyagok leggyakrabban előforduló, nemkívánatos tulajdonsága a változatos formákban megjelenő allergiás reakciók. Ennek hátterében legfőképp a helyi expozíció és a dendritikus sejteken, valamint T-sejteken keresztül történő immunrendszer aktiválódása áll. Leggyakrabban IV-es típusú (késői), valamint nagyon ritkán I-es típusú (azonnali) reakciókkal találkozunk. A klinikai tünetek széles skálán mozognak, a helyileg jelentkező periorális ekcémától kezdve a távoli szervekben jelentkező tüneteken át [26].

A fogorvoslásban használt anyagok biztonságosságát erős jogi háttér biztosítja. Minden gyártónak kötelessége a termék kereskedelmi forgalomba hozatala előtt különböző vizsgálatok elvégzése, melyek bár országonként mutathatnak eltéréséket, a céljuk ugyanaz: a gyógyászati eszköz biztonságosságának garantálása, ami jelen esetben az elfogadhatatlan rizikók hiányát jelenti. Régen ezekre a vizsgálatokra állati modellnek többek között kutyát használtak, ilyen kísérletben bizonyították be például először a maradék dentin fogbél védelmében betöltött szerepét is. A mai modern tesztek sejtkultúra vizsgálatokon nyugszanak, ahol a tesztelt anyagoknak elsődlegesen nem specifikusan a szájüregi- és fogszövet károsító hatásait vizsgálják (citotoxicitás, mutagenitás). Kistestű állatokon (úgynevezett másodlagos vizsgálatok) bőr/nyálkahártya irritáció és szisztémás toxikus hatás megfigyelése történik, de lehetőség van akár IV-es típusú, szenzitizációs vizsgálatokra is. Végül, kísérleti állatokban, emberi pácienseknek megfelelő módon történik az anyag használata [30]. Napjainkban speciális, célsejt tenyészeteket fejlesztettek ki az állati modellek lecserélésére, ilyen például a dentin barrier teszt, amikor egy dentinlemez egyik oldalán pulpális sejteket szimuláló telep található, a másik felszínére pedig a vizsgálandó vegyület vagy anyag kerül felvitelre [28]. A klinikumban természetesen teljesen nem lehet kikerülni az anyagok előre nem várt, kedvezőtlen hatásait, ennek követésére minden országban müködik egy mellékhatás bejelentő hálózat, amit a fogorvos köteles használni. A hétköznapi gyakorlatban a nem várt káros hatások és allergiás reakciók a fogászati páciensek körében ritkán fordulnak elő [26]. Mindezek mellett a fogorvos felelőssége a megfelelő anamnézis felvétele és a klinikai vizsgálat, amely alapján kizárható olyan anyagok használata, amelyekre a páciensnek ismert érzékenysége van. Ennél gyakoribb az egészségügyi személyzet körében tapasztalható érzékenységi reakció [21].

\section{Múgyanta bázisú anyagok}

Napjainkban a helyreállító fogászatban nagyrészt dominánssá váltak a szerves fázisként metakrilát bázisú monomereket tartalmazó kompozit tömőanyagok és a velük való kötés kialakításához szükséges adhezív rendszerek. A kompozitokban leggyakrabban alkalmazott monomerek a hidroxi-etil-metakrilát (HEMA), biszfenol A-glicidil-metakrilát (BisGMA), trietilén-glikoldimetakrilát (TEGDMA), uretán-dimetakrilát (UDMA), valamint a 10-metakriloiloxidecil-dihidrogén-foszfát (10-MDP) [10]. Emellett, főleg az adhezív rendszerekben, gyakran előfordul még a 2-metakriloiloxietil-fenilhidrogén-foszfát (Fenil-P) és a 4-metakriloiloxietil-trimellitát-anhidrid (4-META).

A kompozitok még polimerizálatlan állapotban kerülnek a szájüregbe, tehát közvetlen monomerek érintkezhetnek élő szövetekkel, melyekről tudjuk, hogy sejtkárosító tulajdonsággal bírnak [10]. Az applikálást követően a szájüregben zajlik le a polimerizáció, ez azonban sosem tökéletes, mindig maradnak szabad monomerek [41]. Az elkészült kompozit tömés ennek következtében biodegradációra fogékony marad, szabad monomerjeinek vizes közegben történő passzív hidrolízise és enzimatikus reakcók útján történő átalakulása hosszú távon is biológiailag aktív vegyületek utánpótlásaként funkcionálhat [3, 9]. Ezek mennyisége több faktortól is függ. Minél nagyobb kiterjedésű restaurátum készítése történik, a szájba kerülő monomer mennyisége annál nagyobb, viszont első körben jelentősebb az anyag szájüreggel kommunikáló felszínének a nagysága, mint a térfogata [17, 41]. A restaurátum szájba kerülése után közvetlenül a nyálban mérhető monomerek szintje kofferdám gumilepedő használatával elvileg csökkenthető [14]. Ugyanakkor vizeletvizsgálat alapján a szervezetben a monomer, kifejezetten a biszfenol A (BPA) szintje ideiglenesen megemelkedik, ez azonban 2-14 nap elteltével visszaáll a kiindulási állapotra, és ezt a kofferdám használata nem tudta befolyásolni [14, 17, 19]. A monomerek tömésből való kilépését befolyásolja még a monomer tulajdonsága, polaritása, ugyanis a TEGDMA és a HEMA önmaga is hidrofil [9]. Ezenfelül az oldószerként jelenlévő közeg, tehát a nyál összetétele és 
a táplálkozási szokások is befolyással lehetnek, hiszen szerves oldószert, mint az alkohol, tartalmazó közegben a monomer kioldódás magasabb [11]. In vitro körülmények között kimutatták, hogy a restaurátum elkészülte után egy évvel is még történik monomer-felszabadulás, tehát, ha csak kis mennyiségben is, de folyamatos expozíciónak van kitéve a szervezet [23]. A tömés elkészülte utáni monomer-felszabadulás főleg a felszíni morfológia fúróval történő módosításakor, finírozáskor és polírozáskor, illetve használat közben, a kopás által jöhet létre [29]. A felszabaduló monomerek mennyisége csökkenő sorrendben: legnagyobb mennyiségben a HEMA, majd TEGDMA, UDMA és BisGMA [41]. A HEMA és a TEGDMA apoptózison keresztüli citotoxikus hatást fejt ki, mindemellett genotoxikus és mutagén hatásuk is ismert, ezáltal leginkább lokálisan, a gingiva és a pulpa sejtjeiben okozhatnak sejtpusztulást [15, 18, 27, 34, 35, 37]. Amellett, hogy a monomerek önmagunkban is celluláris szabadgyökképző stresszorok, csökkentik a növekvő reaktív oxigénszármazék szint ellen védő glutation (GSH) szintjét, melyek felszaporodása az apoptózis irányába induló jelutakat aktiválja, szintén sejtkárosodást okozva [15, 27, 35]. Monomer indukált DNS szál-törés következtében a sejtciklust is befolyásolják, a sejtek nagy része a ciklus G2 stádiumában marad, míg G1 állapotba $0 \%-u k$ kerül, ezáltal a sejtproliferáció gátolt [34]. Az oxidatív stressz hatására aktiválódik az ataxia-teleangiektázia mutációs (ATM) gén, mely szintén a sejtciklus megállását eredményezheti, amelyek következtében a szövetek regenerációja és megfelelő funkciójának betöltése akadályozott. Következménye még a különböző mitogén-aktivált protein kinázok (MAPK), mint a c-jun terminál kináz (JNK) és p38 upregulálódása, melyek szintén az apoptózis irányába mutató jelutat modulálják, sejthalált és szövetpusztulást elősegítve [4]. A TEGDMA és HEMA egyaránt csökkenti a makrofágokban a lipopoliszacharid (LPS) indukált citokintermelést, ezáltal gátolva a CD14 és egyéb, az immunsejtek kontrollált együttmúködéséhez szükséges felszíni antigének expresszióját, ezzel akadályozva a parodontális szövetek megfelelő védő funkciójának betöltését, valamint a fogbél külső ingerekre adott regenerációs, keményszövetképző folyamatokban résztvevő szerepét [5, 31]. Mindemellett a TEGDMA a légzési láncban gátló hatást fejt ki a Komplex I-en, melynek következménye a sejtek apoptózisa és nekrózisa [18]. Ezen túl gátolja a specifikus odontoblast funkciókat, mint az alkalikus foszfatáz aktivitás, mineralizációs képesség, kálcium felhalmozódás és a sialoprotein génexpresszióját [7]. Továbbá a TEGDMA néhány kariogén baktérium proliferiációját is elősegítheti [13]. A HEMA, TEGDMA és BisGMA a gingiva, a nyálkahártya és a pulpa sejtjeire is negatív hatást fejt ki [37]. Amellett, hogy a parodontális sejtekre közvetlen apoptotikus hatásuk is lehet, az általuk bakteriális terhelésre adott immunválaszt is befolyásolják interleukinok és TNF-a (tumor nekrózis faktor alfa) felszabadulás csökkentésével [22]. Néhány aminosav prekurzor, mint a $\mathrm{N}$-acetil cisztein (NAC) segítenek a GSH stresszre adott válaszkori szintézisé- ben, így felmerült a monomereket tartalmazó anyagokba történő integrálásának lehetősége [34]. A sejteknek a reaktív oxigéngyökök, így a monomerek által okozott oxidatív stresszel szembeni ellenálló képességét a NAC mellett egyaránt elősegíti még a $C$ és az $E$ vitamin. $A N A C$ a HEMA-val képes komplexet alkotni, csökkentve annak biológiai aktivitását, elősegítve a sejt túlélését [15, 35]. A felsorolt folyamatok miatt rendkívül fontos, hogy ezek a monomerek minél kisebb mértékben találkozzanak az élő szövetekkel, ehhez természetes segítségünkre lehet a megfelelő vastagságú hátramaradt ép dentin, a fog abszolút izolálása a töméskészítés során, illetve a megfelelő polimerizációs idők betartása, mellyel csökkenthető a szabad monomer mennyisége. A megfelelő polimerizáció biztosításához elengedhetetlen a polimerizációs lámpa teljesítményének ismerete és annak időszakonkénti ellenőrzése. Jelenleg sokakat foglalkoztató téma a BisGMA, pontosabban a BPA kérdés. A BPA önmagában nem szándékos alkotórésze a fogászati kompozitoknak. A BPA gyártási tökéletlenség következtében a BisGMA bázisú anyagoknál megtalálható, valamint az ezekben a kompozitokban szintén előforduló biszfenolA-etoxilát-dimetakrilátnak (BisDMA) a nyál általi, szervezetben történő bomlásterméke [2, 8]. A felmerülő kérdések közé tartozik a hormonális, ösztrogén szerü hatása, összefüggésbe hozták az esetleges csökkent termékenységgel, a pubertás kor idejének befolyásolásával, de neurotoxikus, diabéteszre és elhízásra való hajlam emelésével is [27, 33, 35]. Kísérleti állatokban a terhesség alatti BPA expozíció hatására fogazati hipopláziát, generalizált zománcdefektust és fluorózis jeleit mutató elváltozásokat jegyeztek fel [27]. Más állatkísérletek kimutatták, hogy szisztémás toxikus hatás eléréshez $5 \mathrm{mg} /$ testsúlykg/nap dózist kell elérnie a BPA-nak. Majmokban $400 \mu \mathrm{g} / \mathrm{testsúlykg/nap} \mathrm{dózis} \mathrm{a} \mathrm{tejmirigyek-}$ ben proliferációt, míg ugyanez a mennyiség rágcsálókban viselkedésbeli változást idézett elő [39]. Olea és munkatársainak vizsgálata szerint a BPA felszabadulással járó anyaggal ellátott személyek esetén 1,3-13,3 $\mu \mathrm{g} / \mathrm{test}$ súlykg lehet a BPA terhelés. Mivel ez 3 nap lefolyása alatt mért mennyiség, így átlagosan 0,43-4,43 $\mu \mathrm{g} /$ testsúlykg/nap terheléssel lehet számolni [8]. A BPA szint nem tartós, mindösszesen átmeneti emelkedését igazolják egyéb, nyál- és vizeletvizsgálatot végző kutatások is $[14,17]$. A monomerekkel szembeni expozíció csökkentésére célszerü a kofferdám gumilepedő használata [14], illetve a fotopolimerizációs idő növelése általi magasabb fokú polimerizáció elérése, figyelve arra, hogy a lámpa hőtermelése ne károsítsa a környező lágyszöveteket, valamint a fogbelet [36]. Emellett hasznos lehet a kompozit tömőanyag maximum $55^{\circ} \mathrm{C}$-os előmelegítése (unitip kiszerelésü anyagoknál könnyebben megoldható), ugyanis ezáltal magasabb lesz a monomer konverziós ráta, és még elkerülhető a hőhatás miatti pulpakárosodás is. Hátránya, hogy a zsugorodást negatívan befolyásolja, így nagy mennyiségű tömőanyag egyben történő üregbe helyezése kontraindikált [43]. A fogbél felé történő káros hatás kivédésére kis és kö- 
zepes mélységű kavitásokban az adhezív rendszerek megfelelő használata esetén a 0,5-1 mm vastagságig megmaradó ép dentin szignifikánsan, pulpára káros szint alá képes csökkenteni a diffundáló monomerek koncentrációját [32], önsavazó rendszereknél 300 mikron vastagság esetén sem volt a pulpára semmiféle toxikus hatás [12]. A szabad monomerek mennyisége, ezáltal mind a pulpára, mind a környező szövetekre és szervezetre gyakorolt esetleges károsító hatás csökkenthető lehet potensebb fotoiniciátor/aktivátor molekulák használatával. Erre irányuló kísérletek szerint a difenil-foszfinoxid (TPO) nagyobb reaktivitása miatt, magasabb fokú monomer polimer átalakulást eredményez. Hátránya, hogy maga a TPO magasabb citotoxicitással rendelkezik, mint a jelenleg legelterjedtebb kámforkinon [16, 40]. Lehetőség van még a napjainkban egyre inkább elterjedőben lévő bulk-fill kompozitok használatára. Biokompatibilitását tekintve konvencionális és bulk-fill anyagot ugyanazon módon alkalmazva az utóbbi esetében szignifikánsan csökkent a DNS károsító, ezáltal citotoxikus hatása [38]. Jelen ismeretek alapján a múgyanta alapú anyagok megfelelő körültekintéssel, a gyártó által javasolt előírásokat követve biztonsággal használhatók. Múgyanta bázisú ragasztócementek esetében a kompozitoknál már említett kérdések merülnek fel, de vizsgálatok alapján használatuk biztonságosnak bizonyult [6].

A kompozit típusú helyreállító anyagok használata nagy körültekintést igényel a fogtechnikusok számára is. A legtöbb esetben por-folyadék kiszerelésben található anyag pora a levegőben szállva belélegezhető, a folyadék pedig illékony, ezért védőfelszerelés használata kötelező. Feldolgozás közben a még meg nem kötött anyag a használt latex vagy nitril bázisú kesztyúkön is néhány perc alatt átdiffundál, így a bőrrel érintkezve kontakt allergiát alakíthat ki [24, 33]. Ebből kifolyólag a paszta állapotban lévő anyagok használata során is kerülni kell az azzal való érintkezést, valamint figyelni kell az anyag kezelését megkönnyítő primer folyadékok tárolóinak zárására a belélegzés miatti expozíció csökkentésének érdekében is.

\section{Nanorészecskék}

Bár eddig kevesen tulajdonítottak a nanorészecskéknek jelentőséget, egyre inkább előtérbe kerülnek a fogászati anyagok gyártása, használata, feldolgozása és funkcióban eltöltött ideje alatt létrejövő nanorészecskék. Európai uniós szabványok szerint nanorészecskének számítanak az olyan anyagok, amelyek kiterjedése legalább egy dimenzióban 1-100 nm közötti méret közötti. Ha a kiterjedés egyik irányban szignifikánsan (legalább háromszor) nagyobb, akkor nanoszál, nanorúd, nanolemez vagy nanotárgy megnevezést használunk. Az alapján, hogy szétbontható-e kisebb alkotókra, megkülönböztetünk nanorészecskét, aggregátumot és agglomerátumot. Szabvány szerint nem kell közöttük különbséget tenni, biológiai szempontból azonban az egymáshoz lazábban kötött alkotókból álló és nagy összfelszínnel rendelkező nanorészecskék és agglomerátumok nagyobb eséllyel okoznak szöveti reakciókat [29]. Ezen részecskék zsigeri szervekbe, a nyirokrendszerbe bejuthatnak, ezáltal pedig testszerte eljuthatnak távoli pontokra. A nanorészecskék belélegzésének a légzőszervrendszerre való káros hatása kimutatott, kifejezetten, ha valamilyen krónikus gyulladásos betegségben szenved a páciens, mint asztma vagy krónikus-obstrukciós tüdőbetegség (COPD), valamint az sem kizárt, hogy kardiovaszkuláris események kiváltó tényezője is lehet. Különböző nanorészecskék más hatást fejtenek ki összetételtől, morfológiától és szennyezettségtől függően. Fogászatban ilyen méretű töltőanyagot tartalmazhatnak kötött állapotban a kompozitok is. Nanorészecskékkel találkozhat a fogtechnikus és a fogászati csapat is munkája során, az ő esetükben az expozíció mértékének csökkentésére védőfelszerelés használata javasolt. Bár a kompozitokban elsődlegesen kötött formában, főleg makro tartományban vannak jelen az alkotóelemek, azonban sok esetben az elkészítés során vagy szájba kerülés után ezek korrekcióra szorulnak. Ilyenkor, a felszín abrazív változtatása közben nano méretű részecskék kerülhetnek a levegőbe. Az esetleges veszély elkerülése érdekében vízhútés mellett javasolt dolgozni, ugyanis a vízpermet a részecskék nagy részét a levegőben megköti [29, 30]. Egy, a Föld nyugati féltekéjén lévő városban élő ember hétköznapi nanorészecske bevitele átlagosan nagyjából $400 \mu \mathrm{g} / \mathrm{nap}$. Legrosszabb becslések alapján is egy munkanap alatt a fogorvos $20 \mu \mathrm{g}$ nanorészecskével találkozik. Több mint 20 direkt restaurátummal rendelkező páciens esetén a legrosszabb esetben is a kopás következtében a nanorészecske terhelés nem haladja meg a $221 \mu g$-ot naponta. Ebből látszik, hogy fiziológiás körülmények között ettől nem kell tartani, ennek ellenére az elővigyázatosság továbbra is ajánlott, kiváltképp a fogászati és fogtechnikai munkavégzés során [29, 30].

\section{Következtetések}

Amennyiben a páciens bármiféle nem kívánt hatásról számol be, esetleg a fogorvosi vizsgálat alatt a fogászati team felfedez valamilyen elváltozást, elsődlegesen a fogorvos feladata eldönteni, hogy az elváltozás öszszefüggésben állhat-e a szájüregben található fogászati anyagokkal. Amennyiben igen, érdemes lehet a pácienst allergiavizsgálatra küldeni, majd később az elváltozást, káros hatást bizonyítottan okozó anyagot cserélni. Mind a beteg, mind az egészségügyi személyzet esetében az allergizáció esélyének csökkentésére és a káros hatások kivédésére célszerü az ajánlott védőfelszerelések, mint a (részecskeszűrős) orrszájmaszk, védőszemüveg, valamint egyszer használatos kesztyűk használata.

Ma egy gyakorló fogorvos számtalan megoldás és anyag közül választhat munkája során, ezek végletekig megvalósuló, tökéletes ismerete sajnos nem valós op- 
ció. Minden gyógyászati eszköznek megvannak a maga rizikói, viszont minden esetben mérlegelni kell a várható haszon árát az esetleges mellékhatásokkal szemben. Csak olyan anyagok kerülhetnek forgalomba, melyek, a megfelelő használati utasításokat és mind a páciens, mind az egészségügyi csapat védelmét szolgáló előirásokat követve biztonsággal alkalmazhatók. Ha egy fogorvos ismeri az anyagcsoportot, amihez nyúl, akkor az apró, gyártói eltérések miatt a használati utasításokat elolvasva és betartva nyugodtan, bármiféle károkozást elkerülve fogja tudni azt használni.

\section{Rövidítés jegyzék}

10-MDP: 10-metakriloiloxidecil-dihidrogén-foszfát

4-META: metakriloiloxietil-trimellitát-anhidrid

ATM: ataxia-teleangiektázia mutációs

BisDMA: biszfenol-A-etoxilát-dimetakrilát

BisGMA: biszfenol A-glicidil-metakrilát

BPA: biszfenol A

COPD: krónikus-obstrukciós tűdőbetegség

Fenil-P: 2-metakriloiloxietil-fenil-hidrogén-foszfát

GSH: glutation

HEMA: hidroxi-etil-metakrilát

JNK: (c-jun-terminal kinase) c-jun terminál kináz

LPS: lipopoliszacharid

MAPK: mitogén-aktivált protein kináz

NAC: $\quad \mathrm{N}$-acetil cisztein

TEGDMA: trietilén-glikol-dimetakrilát

TNF- $\alpha$ : tumor nekrózis faktor alfa

TPO: difenil-foszfinoxid

UDMA: uretán-dimetakrilát

\section{Irodalom}

1. Accorinte MLR, Loguercio AD, Reis A, Costa CAS: Response of human pulps capped with different self-etch adhesive systems. Clin Oral Investig 2008; 12: 119-127. https://doi.org/10.1007/ s00784-007-0161-9

2. Atkinson JC, Diamond F, Eichmiller F, Selwitz R, Jones G: Stability of bisphenol A, triethylene-glycol dimethacrylate, and bisphenol A dimethacrylate in whole saliva. Dent Mater 2002; 18: 128-135. https://doi.org/10.1016/S0109-5641(01)00031-8

3. Durner J, Spahl W, Zaspel J, Schweikl H, Hickel R, Reichl F-X: Eluted substances from unpolymerized and polymerized dental restorative materials and their Nernst partition coefficient. Dent Mater 2010; 26: 91-99. https://doi.org/10.1016/j.dental.2009.08.014

4. Eckhardt A, Gerstmayr N, Hiller K-A, Bolay C, Waha C, SpagnuOLO G, et al: TEGDMA-induced oxidative DNA damage and activation of ATM and MAP kinases. Biomaterials 2009; 30: 2006-2014. https://doi.org/10.1016/j.biomaterials.2008.12.045

5. Eckhardt A, Harorli T, Limtanyakul J, Hiller K-A, Bosl C, Bolay C, et al: Inhibition of cytokine and surface antigen expression in LPSstimulated muri-ne macrophages by triethylene glycol dimethacrylate. Biomaterials 2009; 30: 1665-1674. https://doi.org/10.1016/ j.biomaterials.2008.09.024

6. da Fonseca Roberti Garcia L, Pontes ECV, Basso FG, Hebling J, dE Souza Costa CA, Soares DG: Transdentinal cytotoxicity of resin-based luting cements to pulp cells. Clin Oral Investig 2016; 20: 1559-1566. https://doi.org/10.1007/s00784-015-1630-1
7. Galler KM, Schweikl H, Hiller K-A, Cavender AC, Bolay C, D'SouzA RN, et al: TEGDMA reduces mineralization in dental pulp cells. J Dent Res 2011; 90: 257-262. https://doi.org/10.1177/ 0022034510384618

8. Goldberg M, Dimitrova-Nakov S, Schmalz G: BPA from dental resin materi-al: where are we going with restorative and preventive dental biomaterials? Clin Oral Investig 2014; 18: 347-349. https://doi.org/10.1007/s00784-013-1153-6

9. Gupta SK, Saxena P, Pant VA, Pant AB: Release and toxicity of dental resin composite. Toxicol Int 2012; 19: 225-234. https://doi. org/10.4103/0971-6580.103652

10. Hermann P, Kivovics $P$, KóBor A: Fogpótlástani anyagtan és odontotechnológia. Budapest: Semmelweis Kiadó és Multimédia Stúdió, 2015; 41.

11. Hope E, Reed DR, Moilanen LH: Potential confounders of bisphenol-a analysis in dental materials. Dent Mater 2016; 32: 961-967. https://doi.org/10.1016/j.dental.2016.05.001

12. Jiang RD, LiN H, Zheng G, Zhang XM, Du Q, Yang M: In vitro dentin barrier cytotoxicity testing of some dental restorative materials. J Dent 2017; 58: 28-33. https://doi.org/10.1016/j.jdent. 2017.01.003

13. Khalichi P, CVitkovitch DG, Santerre JP: Effect of composite resin biodegra-dation products on oral streptococcal growth. Biomaterials 2004; 25: 5467-5472. https://doi.org/10.1016/j.biomaterials. 2003.12.056

14. Kingman A, Hyman J, Masten SA, Jayaram B, Smith C, Eichmiller $F$, et al: Bisphenol $A$ and other compounds in human saliva and urine associated with the placement of composite restorations. J Am Dent Assoc 2012; 143: 1292-1302. https://doi.org/10.14219/ jada.archive.2012.0090

15. Krifka S, Spagnuolo G, Schmalz G, Schweikl H: A review of adaptive mechanisms in cell responses towards oxidative stress caused by dental resin mo-nomers. Biomaterials 2013; 34: 45554563. https://doi.org/10.1016/j.biomaterials.2013.03.019

16. Manojlovic D, Dramićanin MD, Miletic V, Mitić-Ćulafić D, JovaNović B, Niкolić B: Cytotoxicity and genotoxicity of a low-shrinkage monomer and monoacylphosphine oxide photoinitiator: Comparative analyses of individual toxi-city and combination effects in mixtures. Dent Mater 2017; 33: 454-466. https://doi. org/10.1016/j.dental.2017.02.002

17. Maserejian NN, Trachtenberg FL, Wheaton OB, Calafat AM, RangaNathan G, KIM H-Y, et al: Changes in urinary bisphenol A concentrations asso-ciated with placement of dental composite restorations in children and adolescents. J Am Dent Assoc 2016; 147: 620-630. https://doi.org/10.1016/j.adaj.2016.02.020

18. Mikulás K, Hermann P, Gera I, Komlódi T, Horváth G, Ambrus A, et al: Triethylene glycol dimethacrylate impairs bioenergetic functions and in-duces oxidative stress in mitochondria via inhibiting respiratory Complex I. Dental Materials 2018; 34: e166-e181 https://doi.org/10.1016/j.dental.2018.03.012

19. Mikulás K, Linninger M, Takács E, Kispélyı B, Nagy K, Fejérdy $P$ et al: Paradigmaváltás a fogmegtartó kezelésben: az amalgámkorszak vége. Orvosi Hetilap 2018; 159: 1700-1709. https://doi. org/10.1556/650.2018.31215

20. Mittermüller P, Hiller K-A, Schmalz G, Buchalla W: Five hundred pati-ents reporting on adverse effects from dental materials: Frequencies, complaints, symptoms, allergies. Dent Mater 2018; 34: 1756-1768. https://doi.org/10.1016/j.dental.2018.09.012

21. Munksgaard EC, Hansen EK, Engen T, Holm U: Self-reported occupational dermatological reactions among Danish dentists. Eur $J$ Oral Sci 1996; 104: 396-402. https://doi.org/10.1111/j.1600-0722. 1996.tb00098.x

22. Neves So, Magalhães LMd, Corrêa JD, Dutra Wo, Gollob KJ, Silva TA, et al: Composite-derived monomers affect cell viability and cytokine expression in human leukocytes stimulated with Porphyromonas gingivalis. J Appl Oral Sci 2019; 27: e20180529. https://doi.org/10.1590/1678-7757-2018-0529

23. PUTZEYS E, NYS SD, COKIC SM, DUCA RC, VANOIRBEEK J, GODDERIS L, et al: Long-term elution of monomers from resin- 
based dental composites. Dent Mater 2019; 35: 477-485. https:// doi.org/10.1016/j.dental.2019.01.005

24. Sananez A, Sanchez A, Davis L, Vento Y, Rueggeberg F: Allergic reaction from dental bonding material through nitrile gloves: Clinical case study and glove permeability testing. $J$ Esthet Restor Dent 2019; https://doi.org/10.1111/jerd.12546

25. Schmalz G: Materials science: biological aspects. J Dent Res 2002; 81: 660-663. https://doi.org/10.1177/154405910208101001

26. Schmalz G, BindsLev DA: Biocompatibility of Dental Materials [Internet]. Berlin-Heidelberg: Springer-Verlag, 2009

27. Schmalz G, Galler KM: Biocompatibility of biomaterials - Lessons learned and considerations for the design of novel materials. Dent Mater 2017; 33: 382-393. https://doi.org/10.1016/j.dental. 2017.01.011

28. Schmalz G, Gröppl F, Hiller K-A, Galler KM: Three-Dimensional Human Cell Cultures for Cytotoxicity Testing of Dental Filling Materials. Acta Stomatol Croat 2014; 48: 99-108. https://doi. org/10.15644/asc48/2.99

29. Schmalz G, Hickel R, van Landuyt KL, Reichl F-X: Nanoparticles in dentistry. Dent Mater 2017; 33: 1298-1314. https://doi.org/10. 1016/j.dental.2017.08.193

30. Schmalz G, Hickel R, van Landuyt KL, Reichl F-X: Scientific update on nanoparticles in dentistry. Int Dent J 2018; 68: 299-305. https://doi.org/10.1111/idj.12394

31. Schmalz G, KrifKa S, SchweikL H: Toll-like receptors, LPS, and dental monomers. Adv Dent Res 2011; 23: 302-306. https://doi. org/10.1177/0022034511405391

32. Schmalz G, Schuster U, Thonemann B, Barth M, Esterbauer S: Dentin barrier test with transfected bovine pulp-derived cells. J Endod 2001; 27: 96-102. https://doi.org/10.1097/00004770 $-200102000-00009$

33. Schmalz G, Widbiller M, Galler KM: Material Tissue InteractionFrom To-xicity to Tissue Regeneration. Oper Dent 2016; 41: 117131. https://doi.org/10.2341/15-249-BL
34. Schweikl H, Hartmann A, Hiller K-A, Spagnuolo G, Bolay C, BrockHOFF G, et al: Inhibition of TEGDMA and HEMA-induced genotoxicity and cell cycle arrest by N-acetylcysteine. Dent Mater 2007; 23: 688-695. https://doi.org/10.1016/j.dental.2006.06.021

35. Schweikl H, Spagnuolo G, Schmalz G: Genetic and cellular toxicology of dental resin monomers. J Dent Res 2006; 85: 870-877. https://doi.org/10.1177/154405910608501001

36. Spranley TJ, Winkler M, Dagate J, Oncale D, Strother E: Curing light burns. Gen Dent 2012; 60: e210-214.

37. Tadin A, Marovic D, Galic N, Kovacic I, Zeljezic D: Compositeinduced toxicity in human gingival and pulp fibroblast cells. Acta Odontol Scand 2014; 72: 304-311. https://doi.org/10.3109/ 00016357.2013 .824607

38. Tauböck TT, Marovic D, Zeljezic D, Steingruber AD, Attin T, TARLE Z: Genotoxic potential of dental bulk-fill resin composites. Dent Mater 2017; 33: 788-795. https://doi.org/10.1016/j.dental. 2017.04.011

39. Tharp AP, Maffini MV, Hunt PA, VandeVoort CA, Sonnenschein C, Sото AM: Bisphenol $A$ alters the development of the rhesus monkey mammary gland. Proc Natl Acad Sci USA 2012; 109: 81908195. https://doi.org/10.1073/pnas.1120488109

40. van Landuyt KL, Krifka S, Hiller K-A, Bolay C, Waha C, van MeerBEEK B, et al: Evaluation of cell responses toward adhesives with different photoiniti-ating systems. Dent Mater 2015; 31: 916-927. https://doi.org/10.1016/j.dental.2015.04.016

41. van Landuyt KL, Nawrot T, Geebelen B, DE Munck J, Snaumaert J, Yos-HiHaRa K, et al: How much do resin-based dental materials release? A meta-analytical approach. Dent Mater. 2011; 27: 723-747. https://doi.org/10.1016/j.dental.2011.05.001

42. WiLLIAMS DF: On the mechanisms of biocompatibility. Biomaterials 2008; 29: 2941-2953. https://doi.org/10.1016/j.biomaterials. 2008.04.023

43. XUE J, YANG B-N: [Effect of preheating on the properties of resin composite]. Hua Xi Kou Qiang Yi Xue Za Zhi 2019; 37: 571-576.

\begin{abstract}
Review
Barna BK, Fráter M

Resin based composite restorative materials and their effect on oral and general health Literature review

In dentistry, more and more new materials are becoming commercially available to facilitate a more perfect healing activity. It has to be realized that beyond their restorative function in the tooth or in the oral cavity by themselves, these materials are also placed into a dinamically changing medium, thereby they interact not only with their direct environment, but with the whole organism. Keeping this in mind, it is mandatory to know not only about their properties and handling, but also their local and systematic effects in order to minimize or avoid the potential harmful impact on the tissues or on the whole body. The authors with this review would like to give an insight, a small guideline for the daily use of resin based materials, based on the international and Hungarian scientific literature data. The goal is, besides reinforcing our knowledge, to create a safer conditions and environment for the patient, the dentist, and the whole medical team during treatment for the patient, the dentist, and the whole medical team.
\end{abstract}

Keywords: biocompatibility, composite, monomer, resin 